\title{
PENDIDIKAN PRALAHIR: MENINGKATKAN KECERDASAN ANAK DENGAN BACAAN AL-QUR'AN
}

\author{
Kusrinah \\ Fakultas Ilmu Tarbiyah dan Keguruan \\ IAIN Walisongo Semarang
}

\begin{abstract}
Abstrak
Pendidikan anak dimulai sejak masih dalam kandungan sebab masa-masa selanjutnya sangat ditentukan oleh masa anak dalam kandungan. Semenjak dalam kandungan janin sudah melewati proses belajar. Janin sudah mulai bisa mendengar dengan jelas pada usia enam bulan dalam kandungan sehingga ia dapat menggerak-gerakkan tubuhnya sesuai dengan irama nada suara ibunya. Al-Qur'an adalah mukjizat yang telah Allah jamin kemurniannya hingga hari kiamat kelak. Ada banyak kemuliaan dan kebaikan yang ada dalam al-Qur'an, salah satunya adalah al-Qur'an dapat merangsang otak anak dan meningkatkan intelegensinya. Hal ini disebabkan karena bacaan al-Qur'an yang dibaca dengan tartil dan sesuai dengan tajwidnya memiliki frekuensi dan panjang gelombang yang mampu mempengaruhi otak secara positif dan mengembalikan keseimbangan dalam tubuh. Al-Qur'an memberikan pengaruh besar jika diperdengarkan kepada bayi.
\end{abstract}

Kata Kunci: pendidikan pra lahir, al-Qur'an, janin

\section{A. Pendahuluan}

Anak merupakan amanah bagi orang tua yang harus dididik dan diarahkan ke jalan yang benar. Pendidikan anak dimulai sejak masih dalam kandungan sebab masa-masa selanjutnya sangat ditentukan oleh masa anak dalam kandungan. ${ }^{1}$ hlm. 10

${ }^{1}$ Mansur, Mendidik Anak Sejak dalam Kandungan, (Yogyakarta: Mitra Pustaka, 2006), 
Beberapa penelitian yang dilakukan oleh para ilmuwan dalam bidang perkembangan pralahir menunjukkan bahwa selama berada dalam rahim, anak dapat belajar, merasa dan mengetahui perbedaan antara gelap dan terang. Kemampuan anak dalam kandungan berkembang cukup baik pada saat kandungan berusia lima bulan sehingga proses pendidikan dan belajar dapat dimulai. ${ }^{2}$ Pertumbuhan anak sudah dimulai sewaktu masih dalam kandungan, maka tidaklah mengherankan kalau Islam mengatakan bahwa pendidikan sudah mulai sejak bayi masih dalam kandungan. ${ }^{3}$

Berdasarkan hasil penelitian, bahwa semenjak dalam kandungan janin sudah melewati proses belajar. Janin sudah mulai bisa mendengar dengan jelas pada usia enam bulan dalam kandungan sehingga ia dapat menggerakgerakkan tubuhnya sesuai dengan irama nada suara ibunya. ${ }^{4}$

F. Rene van de Carr, M.D dkk telah lama melakukan penelitian tentang pendidikan pralahir dan mereka berkesimpulan sebagai berikut:

1. Tampaknya ada suatu masa kritis dalam perkembangan bayi yang dimulai pada sekitar usia lima bulan sebelum dilahirkan dan berlanjut hingga dua tahun ketika stimulasi otak dan latihan-latihan intelektual dapat meningkatkan kemampuan bayi.

2. Stimulasi pralahir dapat membantu mengembangkan orientasi dan keefektifan bayi dalam mengatasi dunia luar setelah ia dilahirkan.

3. Bayi-bayi yang mendapatkan stimulasi pralahir dapat lebih mampu mengontrol gerakan-gerakan mereka serta lebih siap menjelajahi dan mempelajari lingkungan setelah mereka dilahirkan.

4. Para orang tua yang telah berpartisipasi dalam program pendidikan pralahir menggambarkan anak mereka lebih tenang, waspada dan bahagia. $^{5}$

2 Ubes Nur Islam, Mendidik Anak dalam Kandungan Optimalisasi Potensi Anak Sejak Dini, (Jakarta: Gema Insani, 2004), hlm. 2.

${ }^{3}$ Anselly llyas, Mendambakan Anak Shaleh, (Bandung: Al-Bayan, 1995), hlm. 53.

4 Anonim, "Al-Qur'an Vs Mozart: Mana Yang Mencerdaskan Anak?" http:// jihadsabili.wordpress.com/2011/03/12/alqur\%E2\%80\%99an-vs-mozart-mana-yangmencerdaskan-anak/ 12 Maret 2011.

${ }^{5}$ F. Rene dkk dalam Alwiyah Abdurrahman, Cara Baru Mendidik Anak Sejak dalam Kandungan (Bandung: Kaifa) hlm. 4. 
Jakob Pietschig, Martin Voracek dan Anton K. Forman dari university of vienna, Austria telah melakukan penelitian tentang efek musik mozart terhadap kecerdasan janin. Pietschnig dan kawan-kawannya mengumpulkan semua pendapat dan temuan para ahli terkait dampak musik Mozart terhadap tingkat intelegensi seseorang kemudian mereka membuat riset terhadap 3000 partisipator. Berdasarkan penelitian terhadap ribuan partisipator itu, Pietschnig dan rekan-rekannya menyimpulkan bahwa tidak ada stimulus atau sesuatu yang mendorong peningkatan kemampuan spasial seseorang setelah mendengarkan musik Mozart. ${ }^{6}$

Senada dengan Jacob Pietschnig dan kawan-kawannya, sebuah tim peneliti Jerman yang terdiri atas ilmuwan, psikolog, filsuf, pendidik, dan ahli musik mengumpulkan berbagai literatur dan fakta mengenai efek Mozart ini. Mereka mengemukakan bahwa sangat tidak mungkin Mozart dapat membuat seorang anak menjadi jenius.

Lain halnya dengan al-Qur'an, mukjizat yang telah Allah jamin kemurniannya hingga hari kiamat kelak. Ada banyak kemuliaan dan kebaikan yang ada dalam al-Qur'an, salah satunya adalah al-Qur'an dapat merangsang otak anak dan meningkatkan intelegensinya. Hal ini disebabkan karena bacaan al-Qur'an yang dibaca dengan tartil dan sesuai dengan tajwidnya memiliki frekuensi dan panjang gelombang yang mampu mempengaruhi otak secara positif dan mengembalikan keseimbangan dalam tubuh.

\section{B. Makna Pendidikan Anak dalam Kandungan}

Mendidik anak dalam kandungan merupakan suatu pekerjaan yang besar yang membutuhkan motivasi yang kuat, pemikiran, ketelatenan, pengorbanan dan kesungguhan yang nyata dari pihak orang tuanya karena mendidik anak dalam kandungan sungguh berbeda dengan mendidik anak yang sudah lahir atau sudah memasuki sekolah formal. Kata pendidikan berasal dari kata didik yang mendapat imbuhan pen- dan -an. Kata didik mengandung banyak arti, antara lain pelihara, bina, latih, asuh dan ajar. Dengan

${ }^{6}$ Jakob Pietschig, Martin Voracek \& Anton K. Forman, "Mozart effect-Shmozart effect: A meta-analysis", Journal: Intelligence, Vol. 38, No. 3, pp. 314-323, 2010. 
adanya proses tambahan imbuhan tersebut akan memberikan pemahaman dan pengertian yang lebih luas, kompleks, sistematis dan filosofis.

\section{Tujuan Pendidikan Anak dalam Kandungan}

Tujuan pendidikan anak dalam kandungan adalah:

1. Merefleksikan nilai-nilai ajaran agama, sosial budaya dan ilmu pengetahuan yang dimiliki orang tuanya dan sekaligus mengajak bersama anak dalam kandungannya melakukan refleksi nilai-nilai tersebut.

2. Melatih kecenderungan anak dalam kandungan tentang nilai-nilai tersebut di atas dan sekaligus melatih keterampilan amaliah sesuai dengan yang diajarkannya setelah ia dilahirkan dan dewasa nanti.

3. Melatih kekuatan dan potensi fisik dan psikis anak dalam kandungan.

4. Membangun prakesadaran bahasa dan komunikasi (antara anak dalam kandungan dan orang di luar rahim).

5. Meningkatkan rentang konsentrasi, kepekaan dan kecerdasan anak dalam kandungan.

\section{Dasar-dasar Pendidikan Anak dalam Kandungan}

Berikut ini beberapa ayat al-Qur'an yang dapat kita jadikan dasar pentingnya pendidikan anak dalam kandungan:

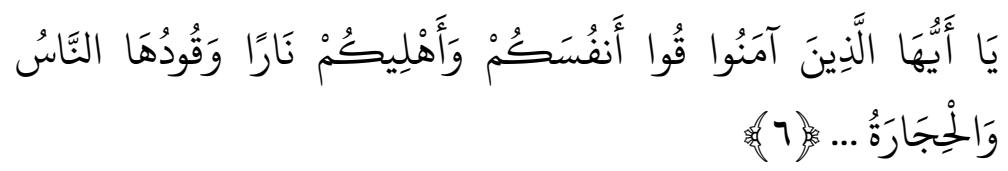

"Hai orang-orang yang beriman peliharalah dirimu dan keluargamu dari api neraka, dimana (neraka) itu bahan bakunya berasal dari manusia dan batu-batuan...." (QS. al-Tahrim [66]: 6)

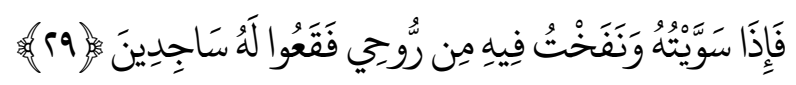

"Maka apabila aku telah sempurnakan kejadiannya dan telah meniupkan ke dalamnya ruh (ciptaan)-Ku, maka tunduklah kamu kepada-Nya dengan sujud." (QS. al-Hijr [15]: 29) 


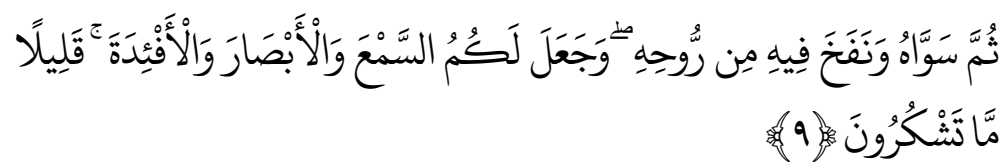

"Kemudian Dia menyempurnakan dan meniupkan ke dalam (tubuh)nya roh (ciptaan)-Nya dan Dia menjadikan bagi kamu pendengaran, penglihatan dan hati, (tetapi) kamu sedikit sekali bersyukur". (QS. al-Sajdah [32]: 9)

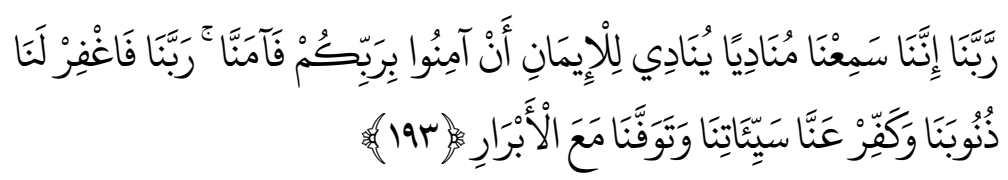

"Ya Tuhan kami, sesungguhnya kami mendengar (seruan)yang menyeru kepada iman, (yaitu) 'berimanlah kamu kepada Tuhanmu' maka kami pun beriman. Ya Tuhan kami, ampunilah bagi kami dosa-dosa kami dan hapuskanlah dari kami kesalahan-kesalahan dan wafatkanlah kami beserta orang-orang yang banyak berbuat baik." (QS. Ali Imran [3]:193)

Hadits riwayat Imam Muslim dari Ibnu Mas'ud:

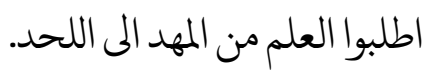

"Carilah ilmu semenjak masa al-mahdi sampai liang lahat."

\section{E. Prinsip-prinsip Pendidikan Anak dalam Kandungan}

Adapun prinsip-prinsip pendidikan anak dalam kandungan, yaitu: ${ }^{7}$

\section{Prinsip Cinta, Kasih, Sayang dan Kerja Sama}

Salah satu di antara kebutuhan esensial manusia secara psikis adalah cinta, kasih dan sayang. Adanya rasa saling cinta, kasih dan sayang dalam keluarga akan menciptakan kedamaian, kerukunan dan hubungan yang seimbang antar suami istri. Keadaan ini dengan sendirinya akan menjadi sarana yang efektif dan efisien pada program pendidikan pralahir.

7 Ubes Nur Islam, Mendidik Anak dalam Kandungan Optimalisasi Potensi Anak Sejak Dini, (Jakarta: Gema Insani, 2004), hlm. 17. 


\section{Prinsip Tauhid}

Dalam melakukan stimulasi edukatif, orangtua harus memberikan nuansa (orientasi) tauhidiyah yaitu latihan-latihan edukasi yang berpangkal pada prinsip-prinsip keesaan Allah.

\section{Prinsip Ibadah}

Orangtua hendaknya memberikan contoh kebiasaan-kebiasaan beribadah bagi anaknya yang sedang tumbuh dan berkembang dalam kandungannya. Dengan pola ini diharapkan akan lahir anak yang tumbuh dan berkembang dalam suasana keaktifan serta sensitif terhadap pelaksanaan menjalankan ibadah.

\section{Prinsip Akhlak dan Kebiasaan Baik}

Contoh keteladanan orangtua kepada anak dalam kandungan yaitu dengan memberikan sensasi-sensasi positif dengan lembut penuh kasih sayang yang berorientasi pada makarimal akhlak seperti berbicara lugas/ jelas, sopan, penuh rasa hormat dan kasih sayang, mengharapkan anak dalam kandungan responsif dan mengulang-ulang latihan/sensasi tersebut dengan rasa tenang dan senang

\section{Prinsip Kecerdasan dan Ilmiah}

Kebiasaan dalam memberikan materi yang dapat memberikan sensasi atau stimulasi pada bayi dalam kandungan diharapkan kelak si anak dapat lebih banyak menerima dan meningkatkan minat da keterampilan pada halhal yang baru. Keadaan tersebut dengan sendirinya akan meningkatkan daya kecerdasan otak dan sensitivitas otak terhadap suasana ilmiah si anak pralahir.

\section{Prinsip Stimulasi Pralahir}

Ketika umur kandungan atau kehamilan telah mencapai lima bulan, maka instrumen indra anak dalam kandungan sudah potensial menerima stimulasi dan sensasi dari luar rahim. Dengan latihan pendidikan pralahir, berarti memberikan stimulasi sistematis bagi otak dan perkembangan saraf bayi sebelum dilahirkan. 


\section{Prinsip Kesadaran Pralahir}

Latihan-latihan pendidikan pra lahir memiliki potensi mengajarkan bayi untuk menyadari bahwa tindakannya mempunyai efek. Dalam permainan bayi menendang, misalnya ketika ia menendang perut ibu di satu tempat, tangan ibu menekan ditempat yang sama. Kenyataan bahwa bentuk stimulasi lingkungan yang diajarkan sebelum kelahiran mempunyai potensi besar dalam mempercepat bayi belajar tentang sebab akibat setelah ia dilahirkan.

\section{Prinsip Keterlibatan Ayah dan Keterlibatan Kakak-kakak Sang Bayi}

Pada dasarnya pendidikan pralahir hanya dapat dilakukan oleh orang tuanya, ibu dan ayahnya. Namun pada kenyataannya, pelaksanaan ini tidak menutup kehadiran anggota keluarga lainnya seperti kakak-kakak sang bayi atau saudara lainnya seperti bibi sang bayi, paman, kakek, nenek dan lainlainnya. Jika orang tuanya, terutama ibunya melakukan stimulasi edukatif komunikasi dialogis interaktif- yang dilakukan secara langsung dengan bayinya yang berada dalam perutnya, maka anggota lainnya melalui perantara, yaitu ibunya.

Keterlibatan ayah sangat penting dan berkaitan erat untuk perkembangan kemampuan sosial sang bayi. Begitu juga keterlibatan kakak-kakak dan anggota keluarga lainnya sang bayi. Hal tersebut, selain meningkatkan kemampuan bersosial bagi sang bayi, juga meningkatkan efektivitas dan keterampilan sang bayi dalam berkomunikasi secara baik, fasih dan andal setelah ia lahir, tumbuh, dan berkembang dewasa nanti.

\section{F. Metode-metode Pendidikan Pralahir}

Metode yang dapat digunakan dalam pendidikan pra lahir antara lain: ${ }^{8}$

\section{Metode Doa}

Doa merupakan instrumen yang sangat ampuh untuk mengantarkan kesuksesan yang sebuah perbuatan. Hal ini dikarenakan segala sesuatu

${ }^{8}$ Ubes Nur Islam, Mendidik Anak dalam Kandungan Optimalisasi Potensi Anak Sejak Dini, (Jakarta: Gema Insani, 2004), hlm. 55 
upaya pada akhirnya hanyalah Allah berhak menentukan hasilnya. Metode doa ini dilakukan pada semua tahapan, tahap zigot, embrio dan fetus. Pada tahap fetus ini hendaknya diikutsertakan melakukan berdoa secara bersamasama dengan ibunya atau ayahnya.

\section{Metode Ibadah}

Segala bentuk ibadah, mahdhah dan ghair mahdhah, wajib dan sunnah seperti shalat, puasa, haji, zakat dapat dijadikan metode untuk mendidik anak dalam kandungan. Besar sekali pengaruh yang dilakukan ibu dengan melakukan metode-metode ibadah ini bagi anak dalam kandungannya selain melatih kebiasaan-kebiasaan aplikasi kegiatan ibadah juga akan menguatkan mental, spiritual dan keimanan anak setelah lahir nanti.

Menerapkan metode ini tidak terlalu sulit, ibu harus lebih kreatif, inovatif dan sungguh-sungguh rela mengikutsertakan segala aktivitas ibadahnya dan anak dalam kandungannya secara bersama-sama.

\section{Metode Membaca dan Menghafal}

Membaca merupakan salah satu cara yang paling utama untuk memperoleh berbagai informasi penting dan ilmu pengetahuan.

\section{Metode Zikir}

Zikir adalah aktivitas sadar pada setiap waktu atau sewaktu-waktu. Metode zikir dapat berupa zikir dalam arti umum atau khusus. Zikir umum berarti ia waspada dan ingat bahwa ia berstatus sebagai hamba Allah di mana setiap kegiatannya tiada lain adalah pengabdian diri kepada Allah semata dalam keseluruhan waktunya. Zikir secara khusus berarti ia melakukan zikir khusus seperti dengan lafal-lafal khusus, tahmid, tahlil, takbir, doa-doa istighatsah, istighfar dan dilakukan sewaktu-waktu sesuai dengan. yang menyertainya.

\section{Metode Instruktif}

Metode ini dimaksudkan tidak saja mengintruksi anak dalam kandungan melakukan aktivitas sebagaimana yang diserukan tetapi juga untuk memberi instruksi kepada bayi melakukan sesuatu perbuatan yang lebih kreatif dan mandiri. 


\section{Metode Dialog}

Metode ini disebut sebagai metode interaktif antara anak dalam kandungan dan orang-orang di luar rahim seperti ibu, ayah, saudarasaudara bayi dan atau anggota keluarga lainnya.

\section{Metode Aktivitas Bersama}

Metode ini menekankan pada kegiatan yang mengajak anak dalam kandungan sesuai dengan kata-kata yng dikondisikan dengan kegiatan alamiah ibunya kemudian secara bersama-sama melakukan perbuatan yng dilakuakan seperti amal saleh, ibadah atau aktivitas lainnya.

\section{Metode Bermain dan Bernyanyi}

Metode ini cukup dilakukan sederhana saja. Misalnya ketika anak dalam kandungan mulai menendang perut atau berputar-putar di sekitar perut maka si ibu hendaknya menyambut dengan kata-kata yang manis penuh kasih sayang, contohnya "adik sayang, ada apa nak? Mari bermainmain dengan ibu" sambil ibu menepuk perut tepat di sekitar tendangan bayi. Lakukan beberapa kali hingga ia berhenti menendang perut si ibu. Kemudian si ibu hendaklah mengakhiri permainan ini dengan nyayian yang merdu hingga bayi betul-betul tertidur.

\section{Metode Kondusif Alamiah}

Metode ini dimaksudkan untuk mengenalkan suasana dan kondisi alam yang berubah-ubah yang tujuannya agar si anak dalam kandungan tidak terkejut oleh perubahan-perubahan yang terjadi karena ia telah mengenal dan merasakan suasana-suasana tersebut dengan kondisi sikap yang tenang.

\section{G. Materi Pelajaran bagi Anak dalam Kandungan}

Berikut beberapa materi pembelajaran bagi anak dalam kandungan:

1. Doa. Materi doa ini terbagi pada tiga tahapan, antara lain: (a) doa pada saat menanamkan benih nutfah, (b) doa pada saat benih sperma telah tertanam di ruang uterus, (c) doa pada saat nuthfah telah menjadi janin. 
2 Praktik ibadah shalat. Anak dalam kandungan direspons untuk melakukan praktik ibadah agar ia terbiasa atau terlatih pada kondisi lingkungan yang aktif dan sensitif dan gemar pada amaliah ibadah yang wajib dan sunnah. Serta melatih gerakan biologis pada tingkat keterampilan maksimal dalam ibadah.

3. Bahasa. Belajar bahasa bagi anak dalam kandungan adalah belajar konsep kata-kata sederhana dan mudah diterima oleh anak. Oleh karenanya, kata-kata yang dapat diterima oleh anak dalam kandungan hanya kata-kata utama yang memiliki konsekuensi fenomenologis sebagaimana yang dialami dan dipahaminya.

4. Al-Qur'an dan al-Hadits. Al-Qur'an adalah imam yang harus diikuti dan pedoman hidup pertamanya sedangkan alhadits adalah pedoman hidup keduanya.

5. Akhlak. Pemberian pendidikan akhlak bagi anak dalam kandungan berarti segala konsekuensi aktivitas yang dilakukan oleh ibunya dalam menjalankan hubungan timbal balik antara si ibu dengan orang lain dalam upaya untuk kebaikan

6. Akidah dan tauhid. Anak dalam kandungan telah menyadari keyakinan tauhid dengan pertolongan cahaya ilahiyah langsung dari Allah.

7. Syari'ah. Peraturan dan hukum-hukum Islam secara umum disebut syari'ah dan secara khusus adalah hukum-hukum amaliah yang termodifikasi dalam hukum fiqih Islam.

8. Pelajaran agama Islam, sejarah Islam dan ilmu pengetahuan. Semua bidang studi atau materi-materi pelajaran yang diajarkan atau dipaketkan dalam kurikulum pendidikan agama Islam dapat dijadikan bahan-bahan materi pelajaran bagi anak dalam kandungan. Caranya, semua pelajaran tersebut dipelajari dan dipahami oleh ibunya atau dibacakan olehnya.

\section{H. Pengaruh Bacaan al-Qur'an}

Pada fase prenatal terjadi pertumbuhan yang penting di dalam rahim ibu. Suasana kesehatan dan kejiwaan ibu sangat mempengaruhi pertumbuhan dan perkembangan anak dalam rahimnya. Rangsangan yang diberikan ibu kepada anaknya dalam rahim sangat penting bagi perkembangan 
selanjutnya. Ibu sebaiknya mengaktifkan komunikasi dengan anak sejak dalam rahim. Memasuki bulan keenam dan ketujuh masa kehamilan, bayi mulai mendengar suara-suara seperti detak jantung ibu, suara usus dan paru-paru, dan juga suara lain di luar rahim. Semua itu didengarkan melalui getaran ketuban yang ada dalam rahim. ${ }^{9}$

Al-Qur'an memberikan pengaruh besar jika diperdengarkan kepada bayi. Hal tersebut diungkapkan Dr. Nurhayati dari Malaysia dalam seminar Konseling dan Psikoterapi Islam di Malaysia pada tahun 1997. Menurut penelitiannya, bayi yang berusia 48 jam yang kepadanya diperdengarkan ayatayat al-Qur'an menunjukkan respon tersenyum dan menjadi lebih tenang.

Ada banyak kemuliaan dan kebaikan yang ada dalam al-Qur'an. Salah satunya adalah al-Qur'an dapat merangsang perkembangan otak anak dan meningkatkan intelegensinya. Setiap suara atau sumber bunyi memiliki frekuensi dan panjang gelombang tertentu. Nah, ternyata, bacaan al-Qur'an yang dibaca dengan tartil yang bagus dan sesuai dengan tajwid memiliki frekuensi dan panjang gelombang yang mampu mempengaruhi otak secara positif dan mengembalikan keseimbangan dalam tubuh.

Al-Qur'an memiliki efek yang sangat baik untuk tubuh, seperti: memberikan efek menenangkan, meningkatkan kreativitas, meningkatkan kekebalan tubuh, meningkatkan kemampuan konsentrasi, menyembuhkan berbagai penyakit, menciptakan suasana damai dan meredakan ketegangan saraf otak, meredakan kegelisahan, mengatasi rasa takut, memperkuat kepribadian, meningkatkan kemampuan berbahasa dan sebagainya. Hal ini dikarenakan frekuensi gelombang bacaan al-Qur'an memiliki kemampuan untuk memprogram ulang sel-sel otak, meningkatkan kemampuan, serta menyeimbangkannya.

Otak telah tumbuh jauh sebelum bayi lahir. la telah mulai bekerja yang hasilnya merupakan benih penginderaan berdasarkan prioritas. Umumnya pendengaran lebih dulu. Jadi, selama masa itu penting sekali untuk selalu menghadirkan lingkungan kondusif dan baik bagi perkembangan otaknya.

${ }^{9}$ A.Y.Mustofa, Panduan Mengajar Bayi Membaca al-Qur'an Sejak dalam Kandungan, (Ambarawa: PGTQA, 2002), hlm. 3. 
Hilangnya lingkungan ini hanya akan membuat otak menderita dan menganggur yang gilirannya mempengaruhi tingkat kecerdasannya.

Pada asalnya, milyaran sel saraf dalam otak manusia bergetar secara konstan. Sel ini berisi program yang rumit dimana milyaran sel-sel di sekitar berinteraksi dalam sebuah koordinasi yang luar biasa yang menunjukkan kebesaran Allah. Sebelum bayi lahir, sel-sel otaknya mulai bergetar berirama secara seimbang. Tapi setelah kelahirannya, tindakan masing-masing akan mempengaruhi sel-sel otak dan cara mereka bergetar. Jadi jika beberapa sel otak tidak siap untuk mentoleransi frekuensi tinggi, ini dapat menyebabkan gangguan dalam sistem getar otak yang pada gilirannya menyebabkan penyakit fisik dan psikologis.

Dalam musik terkandung komposisi not balok secara kompleks dan harmonis, yang secara psikologis merupakan jembatan otak kiri dan otak kanan, yang output-nya berupa peningkatan daya tangkap/konsentrasi. Ternyata al-Qur'an pun demikian, malah lebih baik. Ketika diperdengarkan dengan tepat dan benar, dalam artian sesuai tajwid dan makhraj, al-Qur'an mampu merangsang syaraf-syaraf otak pada anak. Kita semua tahu, neuron pada otak bayi yang baru lahir itu umumnya seperti "disket kosong siap pakai". Artinya, siap dianyam menjadi jalinan akal melalui masukan berbagai fenomena dari kehidupannya. Kemudian akan terciptalah sirkuit dengan wawasan tertentu. Istilah populernya "intelektual". Sedangkan anyaman tersebut akan semakin mudah terbentuk pada waktu dini. Neuron yang telah teranyam di antaranya untuk mengatur faktor yang menunjang kehidupan dasar seperti detak jantung dan bernapas. Sementara neuron lain menanti untuk dianyam, sehingga bisa membantu anak menerjemahkan dan bereaksi terhadap dunia luar.

Selama dua tahun pertama anak mengalami ledakan terbesar dalam hal perkembangan otak dan hubungan antar sel (koneksi). Lalu setahun kemudian otak mempunyai lebih dari 300 trilyun koneksi, suatu kondisi yang susah terjadi pada usia dewasa, terlebih usia lanjut. Makanya para pakar perkembangan anak menyebut usia balita sebagai golden age bagi perkembangan inteligensi anak. 


\section{Kesimpulan}

Anak merupakan amanah dan rizqi dari Allah SWT yang tidak bisa tergantikan dengan apapun, sudah semestinya sebagai orangtua mempersiapkan kehadirannya dengan sebaik-baiknya agar nantinya menjadi anak yang shalih, cerdas dan bermanfaat untuk umat.

Pendidikan Pralahir merupakan serangkaian proses aktivitas manusia yang merupakan kerangka dasar konsep pendidikan anak meliputi prakehamilan sampai masa kehamilan. Pendidikan Pralahir merupakan masa yang akan mempengaruhi pertumbuhan dan perkembangan anak pada masa yang akan datang.

Al-Qur'an merupakan wahyu Allah SWT yang diakui kebenarannya. Al-Qur'an memberikan pengaruh besar jika diperdengarkan kepada bayi. Al-Qur'an mampu merangsang syaraf-syaraf otak pada anak jika diperdengarkan dengan tepat dan benar, dalam artian sesuai tajwid dan makhraj.]

\section{Daftar Pustaka}

Alatas, Alwi, Antara Efek Mozart dan Efek Murottal .

Anonim, "al-Qur'an vs Mozart: Mana yang Mencerdaskan Anak?" http:// jihadsabili.wordpress.com/2011/03/12/alqur\%E2\%80\%99an-vs-mozart-manayang-mencerdaskan-anak/ 12 maret 2011

Dian Adlina, Fitri, "Benarkah al-Qur'an dapat Merangsang Tingkat Intelegensi Anak," http://10091fda.blogspot.com/2011/03/benarkah-al-quran-dapat-merangsang. $\mathrm{html}$

Doni, Koesoma, Pendidikan Karakter, Jakarta: Grasindo, 2007.

Ilyas, Anselly, Mendambakan Anak Shaleh, Bandung: Al-Bayan, 1995.

Mansur, Mendidik Anak Sejak dalam Kandungan, Yogyakarta: Mitrapustaka, 2006.

Mustofa, A.Y., Panduan Mengajar Bayi Membaca al-Qur'an Sejak dalam Kandungan, Ambarawa: PGTQA, 2002.

Nur Islam, Ubes, Mendidik Anak dalam Kandungan Optimalisasi Potensi Anak Sejak Dini, Jakarta: Gema Insani, 2004. 
Pietschig, Jakob, Martin Voracek \& Anton K. Forman, "Mozart effect-Shmozart effect: A Meta-Analysis", Joumal: Intelligence Vol. 38, No. 3, pp. 314-323, 2010.

Rene, F. dalam Alwiyah Abdurrahman, Cara Baru Mendidik Anak Sejak dalam Kandungan, Bandung: Kaifa.

Salwanida, Merencanakan Kecerdasan dan Karakter Anak Sejak dalam Kandungan, Yogyakarta: Katahati, 2010. 